\title{
NOZZLES TRANSVERSE DISTRIBUTION MODEL DEVELOPMENT: EFFECT OF PRESSURE AND ANTI DRIFT NOZZLE
}

\section{RAZVOJ POPREČNE DISTRIBUCIJE RASPRSKIVAČA: EFEKAT PRITISKA I ANTI DRIFT RASPRSKIVAČA}

\section{Višacki Vladimir, Sedlar Aleksandar, Bugarin Rajko, Turan Jan, Kalajdžić Mladen, Ponjičan Ondrej, Ivanišević Mladen}

Faculty of Agriculture, University of Novi Sad, Trg D. Obradovića 8, 21000 Novi Sad, Serbia

e-mail: vladimir.visacki@polj.uns.ac.rs

\begin{abstract}
The efficacy of pesticide application depends not only on the quality of pesticides but also the quality of the application. One of the factor that most influences on the applications quality, from the standpoint of mechanization, are nozzles. They applied liquid on the surface of the plant which resulting that same volume of pesticide is applied to the entire surface of the plants. To achieve this goal, nozzles must performed uniform application of liquid per unit area, or working width. The variable factor in the application of pesticides may be nozzle and operating pressure. With increasing working pressure it was obtained smaller droplets.

The paper presents test of three different nozzles. Each nozzle is characterized by a flat jet with an angle of $110^{\circ}$ and a flow rate of $1.61 / \mathrm{min}$ at a pressure of 3 bar. Differences between each other is the way of jet disintegration. Exactly this characteristic causes that with pressure change coming to changes in the uniformity of nozzles transverse distribution. The best distribution has nozzle with a flat jet. The coefficient of variation is between roughly from 4 to $6 \%$ at the pressure application of 2 to 4 bar.

Obtained mathematical model that describes changes in the coefficient of variation depending on pressure applications can be a good basis for easy harmonization parameters in the pesticide application.

Keywords: nozzle, coefficient of variation, uniformity of distribution, pressure, sprayer, disintegration.

\section{INTRODUCTION}

Today's way of plants protecting require a modern technique for pesticide application. The technique as sprayer must be well chosen, functional, calibrated and maintained. Nozzles are important because of their impact on biological efficiency, environmental protection and weed control efficiency. Their quality is reflected at the work in altered weather conditions, in that they have wide range of operating pressure,
\end{abstract}


flexibility in terms of flow with movement speed change. For efficient application of pesticides, nozzles must be uniformly distributed over the entire surface of boom working width. In this effect is influenced by two components. One of them is a horizontal-enabled application that depends on the boom, the distance between nozzles, nozzles type and exploitation factors. Leung et al. (1990) adds that pressure and height of boom as the operational parameters and that they are the most important for the pesticides uniform application. Nowakowski (2007) states that the pressure plays a major role in the quality of the transverse distribution in terms of variation coefficient. Douzals (2012) in the examination of flat jet nozzles at a pressure of 1.5 bar to 3.5 bar and boom height from 0.3 to $0.9 \mathrm{~m}$ comes to the entire data spectrum of variation coefficient. On that basis he concluded if pressure increases it result to reduction variation coefficient. Rising up to a value of $1.08 \%$ at a pressure of 3.5 bar and the boom height $0.9 \mathrm{~m}$. Similarly, Sawa et al. (2012) confirms indicated by recommending that one of the most important factors just a good selection of nozzles. Nozzles precisely characterized by transverse distribution as the most important factor. This characterizes them and to their most important feature according to Bahadir and Saim (2011). Application in rows is even better technique pesticide application because the treatment is done predefined part (Nigar et al. 2011). Worn or damaged nozzles will not only have a bad transverse distribution of fluids, but also larger droplets Subra et al (2015).

The task was to carry out a measurement of the transverse distribution of three different nozzles in the laboratory. The aim is to show the impact of different types of anti-drift nozzles on the transverse distribution. The resulting mathematical models describing the change at the coefficient of variation of other parameters tested applications for nozzles.

\section{MATERIALS AND METHODS}

In the laboratory control techniques for the application of pesticides is done measuring the transverse distribution of three different nozzles. All nozzles are flow rate of $1.61 / \mathrm{min}$, red in color and are set to triple rack nozzles on the wing length of $6 \mathrm{~m}$ for every $0.5 \mathrm{~m}$. All nozzles were tested at pressures recommended by the manufacturer. These are pressures from 2 to 4 bar or 2 to 6 bar examination every 0.5 bar. Identification of the nozzles $\mathrm{AD}, \mathrm{AD} / \mathrm{D}$ and ADIA. The first nozzle was labeled with $\mathrm{AD}$ is anti drift nozzle with a flat jet angle of $110^{\circ}$. The second is the same as the first but it have only long nozzles body and rotated jet by $30^{\circ}$ in the negative direction. The last tested nozzle was injector nozzle with a spray angle of $110^{\circ}$. Nozzles are shown in the following photos. 
Fig. 1. Tested nozzles

Sl. 1. Ispitivani rasprskivači

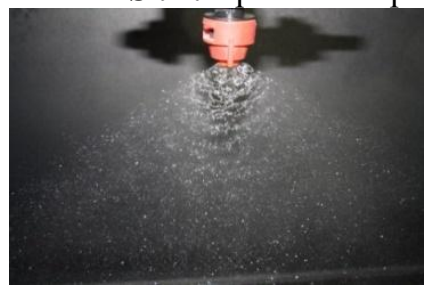

$\mathrm{AD}$

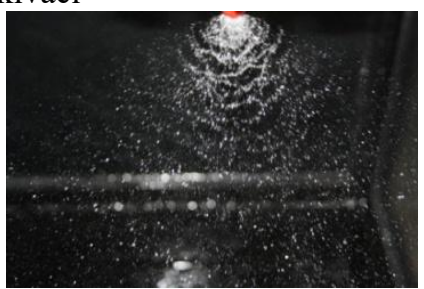

$\mathrm{AD} / \mathrm{D}$

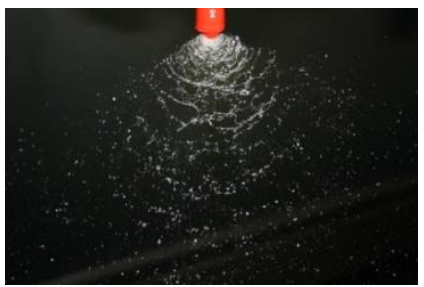

ADIA

Applications height was $0.5 \mathrm{~m}$. The temperature was about $25^{\circ} \mathrm{C}$ and the relative humidity exceeded 65\%. Everything was done in accordance with ISO 16122-2: 2015 Agricultural and forestry machinery - Inspection of sprayers in use - Part 2: Horizontal boom sprayers. Given that the said standard relates to crop sprayers, all measurements were done on crop sprayer. It is a field sprayer, which is used for laboratory purposes, where drive of piston diaphragm pump of $851 /$ min is performed by electric motor. The tank holds 300 liters and measuring and control device is a mechanical pressure gauge with a measuring range up to 8 bar. Booms are $6 \mathrm{~m}$ width and divided into two sections, every $3 \mathrm{~m}$.

For measuring the transverse distribution was used Spray scanner company AAMS Salvarani. The dimension is $1.2 \mathrm{~m} \mathrm{x} 0.8 \mathrm{~m}$ in width which was divided into 8 funnels. All the liquid collected in funnels flowing in tubes of a known volume. The tubes have upper and lower contacts, which measures the time required for filling the tube. In this way, the total flow rate is calculated. On the computer among other parameters, shows the coefficient of variation as a measure of the transverse distribution uniformity. If this ratio is less than $10 \%$, the average distribution nozzles is acceptable. For a coefficient of variation greater than $10 \%$, the horizontal distribution of the working fluid is unacceptable.

\section{Research results with discussion}

By measuring the transverse distribution are obtained coefficient of variation indicated in the following table. In all nozzles were recorded mainly coefficient of variation of less than $7 \%$, which is an excellent horizontal distribution at all tested pressures. Thus, at lower pressures the best lateral distribution has nozzle as $\mathrm{AD}$ at a pressure of 2.5 bar coefficient of variation of only $4.83 \%$. This is less than $7.19 \%$, which has rotated the nozzle spray to $30^{\circ}$ at a pressure of 2 bar. 
Tab. 1. Coefficients of variation of tested nozzles

Tab. 1. Koeficijenti varijacije ispitivanih rasprskivača

\begin{tabular}{crrr}
\hline $\begin{array}{c}\text { Nozzle/ } \\
\text { Pressure, bar }\end{array}$ & AD 110-04 & AD/D 110-04 & ADIA 110-04 \\
\hline 2 & 5,15 & 7,19 & 6,19 \\
2,5 & 4,83 & 6,25 & 5,93 \\
3 & 5,2 & 6,68 & 5,67 \\
3,5 & 5,37 & 6,8 & 5,395 \\
4 & 5,72 & 7,04 & 5,12 \\
5 & $/$ & $/$ & 5,77 \\
6 & $/$ & $/$ & 5,81 \\
\hline
\end{tabular}

At higher pressure applications deteriorates transverse distribution of fluids. In this regard, the dispenser $\mathrm{AD} / \mathrm{D}$ has a higher coefficient of variation of $7 \%$ at a pressure of 4 bar. This is still an acceptable value or distribution is not perfect. At the same pressure distribution has the best horizontal injector nozzle with a spray $5.12 \%$. It is interesting that at higher pressures the coefficient of variation does not increase dramatically with this nozzles and amounts 5,77\% at 5 bar person respectively $5.81 \%$ at 6 bar. This is very important at the application of pesticides. Generally, anti drift nozzle with a fan-shaped jet has the best distribution with a note that statistics do not differ much uniformity from one another.

Fig. 4. Changing coefficient of variation depending on the nozzles type and pressure.

Sl. 4. Promena koeficijenta varijacije u zavisnosti od tipa rasprskivača i pritiska.

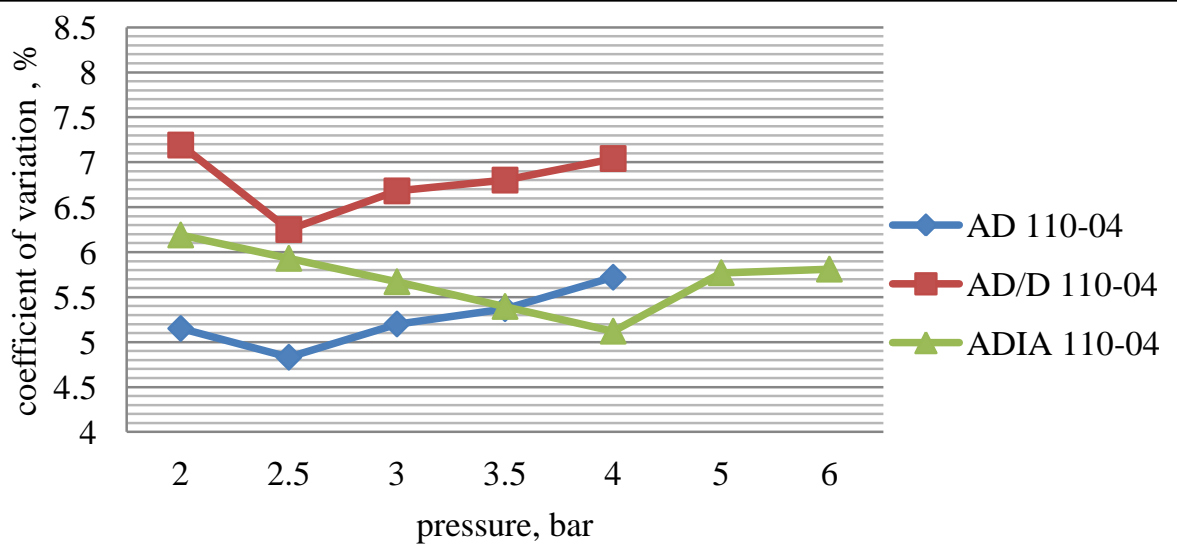

On the previous picture is shown a graph which represent changes variation coefficient with the change of pressure and nozzles type. For all the notes that as the pressure increases, the quality of the transverse distribution improves and then with 
further increasing pressure it start to be worse. However, the changes are not so drastic and have a great impact on the quality of distribution. The equations that describe the change in the coefficient of variation of the following:

AD: $y=-0,042 x^{3}+0,463 x^{2}-1,323 x+6,034 R^{2}=0,945$

ADIA: $y=-0,010 x^{4}+0,175 x^{3}-0,935 x^{2}+1,590 x+5,345, R^{2}=0,873$

AD/D: $y=-0,104 x^{3}+1,083 x^{2}-3,311 x+9,492, R^{2}=0,879$

Given equation can be used to obtain the coefficient of variation for pressures and tested nozzles. They have an important role at application chooses the parameters of crop sprayers and given nozzles.

\section{CONCLUSION}

In examining three different anti drift nozzles at the recommended pressure can conclude the following:

- Best horizontal transverse distribution of the working fluid has a nozzle with $\mathrm{AD}$ coefficient of variation of $4.83 \%$ to $5.72 \%$;

- It is expected that the injector nozzle has the worst distribution but this is not the case, because $\mathrm{AD} / \mathrm{D}$ jet nozzle has rotated by $30^{\circ}$, which leads to lower transverse distribution with a range of $6.25 \%$ to $7.19 \%$;

- Injector nozzle maintains uniform distribution of working liquid despite the high pressures of between 5 and 6 bar.

The obtained equations can be very useful when selecting operational parameters pesticide application. It is necessary to ddatno perform tests at different altitudes because the applications boom is not a course are not always parallel, at a distance of $0.5 \mathrm{~m}$.

\section{LITERATURE}

[1] Nowakowski, T. (2007). Interaction between selected spraying parameters on the variability coefficient of liquid transverse distribution. Inzynieria Rolnicza, 3(91), 135141.

[2] J.P. Douzals, A. Porte, P. Fernandez. Simulating CoV from nozzles spray distribution: a necessity to investigate spray distribution quality with drift reducing surfactants.. CIGRAgEng2012, Jul 2012, Valencia, Spain. CIGR-AgEng, 6 p., 2012.

[3] Alaa Kamel Subra, Józef Sawaa, Stanisław Parafiniuka (2015). Practical deviation in sustainable pesticide application process. Agriculture and Agricultural Science Procedia 7 (2015): 241-248.

[4] Sawa J. Wójcicki Z., Tabor S., Wajszczuk K., 2004. Wpływ nowych technologii na poziom i strukturę nakładów materiałowo-energetycznych na jakość surowców rolniczych. Sprawozdanie końcowe KBN Nr 3 P06R 03722 AR Lublin (maszynopis).

[5] Sawa J. , Huyghebaert B. , Parafiniuk S. , 2012. Testing device for a complex measurement of the performances nozzles ,SPISE 4, Lana, Italy, 228-233.

[6] ISO 16122-2:2015 Agricultural and forestry machinery - Inspection of sprayers in use - Part 2: Horizontal boom sprayers.

[7] Gajtkowski A.: Technika ochrony roślin. Poznań 2000. Wydawnictwo Akademii Rolniczej w Poznaniu, s. 122.

[8] Leunda P, Debouche C, Caussin R (1990). Predicting the transverse volume distribution under an agricultural spray boom. Crop protection Vol. 9, 111-114. 
[9] Nigar Y, Ekrem A, Ali M, Huseyin Y, Nebile D, Tunahan E, Ebru K (2011). Effect of different pesticide application methods on spray deposits, residues and biological efficacy on strawberries. Afr. J. Agric. Res. 6(4):660-670.

[10] Bahadir S, Saim B (2011). Spray distribution uniformity of different types of nozzles and its spray deposition in potato plant. Afr. J. Agric. Res. 6(2):352-362.

[11] J.P. Douzals, M. Al Heidary. How spray characteristics and orientation may influence spray drift in a wind tunnel. International Advances in Pesticide Application 2014, Jan 2014, Oxford, United Kingdom. Association of Applied Biologists, p.271 p.278, 2014.

\section{RAZVOJ POPREČNE DISTRIBUCIJE RASPRSKIVAČA: EFEKAT PRITISKA I ANTI DRIFT RASPRSKIVAČA}

\section{Višacki Vladimir, Sedlar Aleksandar, Bugarin Rajko, Turan Jan, Kalajdžić Mladen, Ponjičan Ondrej, Ivanišević Mladen}

Poljoprivredni fakultet, Univerzitet u Novom Sadu, Trg Dositeja Obradovića 8, 21000

Novi Sad, Srbija

e-mail: vladimir.visacki@polj.uns.ac.rs

\section{ABSTRACT}

Efikasnost primene pesticida zavisi ne samo od kvaliteta pesticida, već i od kvalitet aplikacije. Jedan od faktora koji najviše utiče na kvalitet aplikacije, sa stanovišta mehanizacije, su rasprskivači. Oni nanose tečnost na površinu biljke koja bi trebala da se rasporedi po ceoj površini biljke. Da bi se postigao ovaj cilj, rasprskivač mora izvršiti ujednačenu primenu tečnosti po jedinici površine, ili radnog zahvata. Promenljivi faktor u primeni pesticida može biti tip rasrskivača i radni pritisak. Sa porastom radnog pritiska, dobijene kapljice su sitnije.

U radu je prikazan test tri različita rasprskivača. Svaki rasprskivač karakteriše ravan mlaz sa uglom od $110^{\circ}$ i protokom od 1,6 1/ min pri pritisku od 3 bara. Razlike između rasprskivača je način dezintegracije mlaza. Upravo to karakteristika izaziva da se sa promenom pritiska dolazi do promene u uniformnost poprečni distribucije rasprskivača. Najbolja distribuciju ima rasprskivač sa ravnim mlazom. Koeficijent varijacije je između približno od 4 do $6 \%$ pri pritiska od 2 do 4 bara.

Dobijena matematički model koji opisuje promene u koeficijentu varijacije u zavisnosti od primene pritiska može biti dobra osnova za lako usklađivanja parametara pri aplikaciji pesticida.

Ključne reči: rasprskivači, koeficijent varijacije, uniformnost distribucije, radni pritisak, prskalica, dezntegracija.

Napomena: Rad predstavlja deo istraživanja na projektu TR - 31025: „Razvoj novih sorti i poboljšanje tehnologije proizvodnje uljanih biljnih vrsta za različite namene“, koje finansira Ministarstvu za nauku i obrazovanje Republike Srbije.

Primljeno: 17. 02. 2016. god.

Prihvaćeno: 08. 03. 2016. god. 